\title{
Effects of Typical and Atypical Antipsychotics and Receptor Selective Compounds on Acetylcholine Efflux in the Hippocampus of the Rat
}

\author{
Sudabeh Shirazi-Southall, M.A., Dana Ellen Rodriguez, A.H.T., George G. Nomikos, M.D., Ph.D.
}

\begin{abstract}
Some atypical antipsychotic drugs appear to improve cognitive function in schizophrenia and since acetylcholine $(A C h)$ is of importance in cognition, we used in vivo microdialysis to examine the effects of antipsychotics administered acutely (SC or IP) at pharmacologically comparable doses on ACh outflow in the hippocampus of the rat. The atypical antipsychotics olanzapine and clozapine produced robust increases in ACh up to $1500 \%$ and $500 \%$, respectively. The neuroleptics haloperidol, thioridazine, and chlorpromazine, as well as the atypical antipsychotics risperidone and ziprasidone produced modest increases in ACh by about 50-100\%. Since most atypical antipsychotics affect a variety of monoaminergic receptors, we examined whether selective ligands for some of these receptors affect hippocampal ACh. Antagonists for the 5- $\mathrm{HT}_{2 A}$ (MDL
\end{abstract}

100,907), the 5-HT 2 C (SB 242,084), the 5-HT $($ Ro 04-6790), the $D_{2}$ (raclopride) receptors, and the $\alpha_{1}$-adrenoceptors (prazosin) modestly increased $A C h$ by about $50 \%$. The 5-HT $\mathrm{T}_{1 \mathrm{~A}}$ agonist $\mathrm{R}-(+)-8-\mathrm{OH}-\mathrm{DPAT}$ and the $\alpha_{2}{ }^{-}$ adrenoceptor antagonist yohimbine significantly increased ACh by about $100 \%$ and $50 \%$, respectively. Thus, olanzapine and clozapine increased ACh to a greater extent than other tested antipsychotics, explaining perhaps their purported beneficial effect in cognitive function in schizophrenia. It appears that selective activity at each of the monoaminergic receptors studied is not the sole mechanism underlying the olanzapine and clozapine induced increases in hippocampal ACh.

[Neuropsychopharmacology 26:583-594, 2002] (C) 2002 American College of Neuropsychopharmacology. Published by Elsevier Science Inc.
KEY WORDS: Antipsychotic; Schizophrenia; Olanzapine; Clozapine; Microdialysis; Acetylcholine

From the Neuroscience Discovery Research, Lilly Research Laboratories, Eli Lilly and Company, Lilly Corporate Center, Indianapolis, IN 46285-0510, USA

Address correspondence to: G.G. Nomikos, Neuroscience Discovery Research Eli Lilly and Company Lilly Corporate Center Indianapolis, IN 46285-0510, Tel.: (317) 433-2541, Fax: (317) 276-5546, E-mail: gnomikos@lilly.com

Received May 29, 2001; revised October 8, 2001; accepted October 22, 2001.

Online publication: 10/24/01 at www.acnp.org/citations/ Npp102401193
Impairments in cognitive processes, such as deficits in executive function, verbal memory and attention, are prevalent in most patients with schizophrenia (Breier 1999). Some atypical antipsychotic drugs appear to improve not only the positive symptoms, but also the negative symptoms and the cognitive deficits when compared with classical neuroleptics (Kinon and Lieberman 1996; Meltzer and McGurk 1999; Remington and Kapur 2000). For example, some atypical antipsychotic drugs have been shown to improve attention, motor and executive function in schizophrenic patients (Meltzer and McGurk 1999). It has been well documented that all clinically effective antipsychotic drugs block dopamine D2 receptors in the brain. Additionally, many preclini- 
cal and clinical studies have indicated that atypical antipsychotics, such as clozapine, olanzapine and risperidone, potently inhibit serotonin $5-\mathrm{HT}_{2}$ receptor function and affect a variety of other receptors in the brain (Meltzer et al. 1989; Leysen et al. 1992; Bymaster et al. 1996). In particular, clozapine and olanzapine show a complex pharmacological profile, being described as "multi-acting-receptor-targeted antipsychotic agents" (MARTAs) (Bymaster et al. 2000).

Acetylcholine has been shown to be an important neurotransmitter in motor function, attention and various aspects of cognition. Cholinergic synapses are prevalent in many areas of the brain, including the striatum, the prefrontal cortex and the hippocampus. Neuronal processes within the hippocampus, in particular, mediate declarative memory, and participate in cognitive mapping in both experimental animals and humans (Eichenbaum et al. 1999). It appears likely therefore that a dysfunction in cholinergic neurotransmission within the hippocampus may be responsible for the cognitive impairments often encountered in schizophrenia. In turn, the beneficial effects of some atypical antipsychotic drugs in the treatment of cognitive deficits in schizophrenia may be related to their selective action on cholinergic function in the hippocampus, as a consequence of their multireceptor pharmacological profile.

Earlier in vivo microdialysis experiments have revealed a selective action of clozapine on ACh outflow in limbocortical, dopaminergic regions of the brain, such as the prefrontal cortex, as compared with classical neuroleptics (Parada et al. 1997; Moore et al. 1999). In general, antipsychotic drugs appear to either increase or have no effect on ACh efflux within the striatum, a dopaminergic region of the brain related to motor function (Imperato et al. 1993; Ueda et al. 1995; DeBoer and Abercrombie 1996; Ikarashi et al. 1997; Parada et al. 1997; Moore et al. 1999). To this end, we sought to examine the effects the atypical antipsychotic drugs, olanzapine, clozapine, risperidone and ziprasidone, vis-à-vis the effects of the typical antipsychotic drugs, haloperidol, thioridazine and chlorpromazine, on ACh efflux in the hippocampus of the rat by means of in vivo microdialysis. In order to be able to differentiate between the effects of typical and atypical antipsychotics on ACh outflow, pharmacologically comparable doses of the tested antipsychotics were used, primarily based on ex vivo occupancy data for the $D_{2}$ and/or the 5- $\mathrm{HT}_{2}$ receptors, i.e. doses that achieve considerable occupancy for these receptors (Schotte et al. 1996; Zhang and Bymaster 1999). We also examined the ACh responses to selective ligands for some monoaminergic receptors $\left(\mathrm{D}_{2}, 5-\mathrm{HT}_{2 \mathrm{~A}}, 5-\mathrm{HT}_{2 \mathrm{C}}, 5-\mathrm{HT}_{6}, 5-\mathrm{HT}_{1 \mathrm{~A}}, \alpha_{1}-\right.$ and $\alpha_{2}-$ adrenoceptors) that are targeted by the studied atypical antipsychotic drugs. Thus, we aimed at unraveling the receptor system(s) involved in the tentative differential effects of typical and atypical antipsychotic drugs on hippocampal ACh efflux.

\section{MATERIALS AND METHODS}

\section{Animals and Surgery}

Adult male Wistar rats (250-300 g; Harlan Sprague Dawley, Inc., Indianapolis, IN) were housed under 12-h light/dark cycle (lights on at 7:00 A.M.) in a temperature $\left(23^{\circ} \mathrm{C}\right)$ controlled animal facility with food and water available ad libitum. Rats were anesthetized with a solution containing chloral hydrate (Sigma) and pentobarbital sodium (Bergen Brunswick) and were mounted in a stereotaxic apparatus (Stoelting) with the incisor bar 3 $\mathrm{mm}$ under the horizontal plane passing through the interaural line. Animals were implanted with a guide cannula (Bioanalytical Systems, Inc.) in the hippocampus (coordinates relative to bregma: $\mathrm{AP}=-5.2, \mathrm{ML}=+5.0$, $\mathrm{DV}=-3.8$ ) according to the atlas of Paxinos and Watson (1986). While the animal was still anesthetized, a commercially available microdialysis probe (Bioanalytical Systems, Inc.), with an active membrane surface of 4.0 $\mathrm{mm}$, was inserted through the guide cannula and secured in place. After surgery, rats were housed individually in plexiglass cages. Principles of laboratory animal care (Guide for the Care and Use of Laboratory Animals, National Academy Press 1996) were followed, and all protocols were approved by the Animal Care and Use Committee of Eli Lilly and Company.

\section{Microdialysis Experiments and Biochemical Analysis}

The day prior to microdialysis experiments, rats were transported from their home cage to the microdialysis testing room for habituation. All experiments were performed approximately $48 \mathrm{~h}$ postsurgery in awake, freely moving animals during the light period. Microdialysis experiments and the subsequent biochemical analysis were performed using an automated on-line injection system. On the day of the experiment, microdialysis probes were perfused with a modified Ringer's solution comprised of: $1.3 \mathrm{mM} \mathrm{CaCl}_{2}$ (Sigma), $1.0 \mathrm{mM} \mathrm{MgCl}$ (Sigma), $3.0 \mathrm{mM} \mathrm{KCl}$ (Sigma), $147.0 \mathrm{mM} \mathrm{NaCl}$ (Sigma), $1.0 \mathrm{mM} \mathrm{Na} \mathrm{HPO}_{4} \times 7 \mathrm{H}_{2} \mathrm{O}$ (Malinckrodt), $0.2 \mathrm{mM}$ $\mathrm{NaH}_{2} \mathrm{PO}_{4} \times 2 \mathrm{H}_{2} \mathrm{O}$ (Malinckrodt) and $0.3 \mu \mathrm{M}$ neostigmine bromide (Sigma) (pH 7.2) at a rate of $2.4 \mu \mathrm{l} / \mathrm{min}$ set by a microinfusion pump (Scipro). The dialysate was loaded directly into a $100 \mu \mathrm{l}$ sample loop of the injector (Valco Instruments Co.) and automatically injected into the analytical system (ESA, Inc.) every 15 min. The loading and injecting modes of the injector were computer driven (EZ Chrom software, Scientific Software). Dialysate concentrations of acetylcholine were determined by high-performance liquid chroma- 
tography with electrochemical detection (HPLC-ED), with a $150 \times 3 \mathrm{~mm}$ ACH-3 column (ESA, Inc.) maintained at $35^{\circ} \mathrm{C}$. The mobile phase was comprised of 100 $\mathrm{mM}$ di-Sodium hydrogen phosphate (Fluka), $2.0 \mathrm{mM}$ 1-octanesulfonic acid (Sigma), and $100 \mu \mathrm{l} / 2 \mathrm{~L}$ of reagent MB (ESA, Inc.) ( $\mathrm{pH}$ 8.0, adjusted with phosphoric acid) and was delivered by an HPLC pump (ESA, Inc.) at 0.4 $\mathrm{ml} / \mathrm{min}$. Pulse-dampeners (Alltech) were placed between the HPLC pump and injector. A coulometric detector was used for electrochemical detection (ESA Coulochem II) connected with a solid phase reactor for acetylcholine (ESA; ACH-SPR) and with an analytical cell with platinum target (ESA model 5041). This configuration allowed enzymatic conversion of acetylcholine in the solid phase reactor followed by electrochemical oxidation of hydrogen peroxide that was produced by the enzyme reactions. Chromatograms were simultaneously collected on a chart recorder (Kipp and Zonnen) and in a computer for further data analysis with the EZ Chrom software (Scientific Software). Under the present experimental conditions, inclusion of the sodium channel blocker tetrodotoxin $(0.1 \mu \mathrm{M}, n=4)$ in the perfusion solution or exclusion of $\mathrm{Ca}^{2+}(\mathrm{n}=4)$ from the perfusion solution decreased ACh outflow to $<20 \%$ of baseline (data not shown), verifying the neuronal origin of the detected ACh.

On completion of the microdialysis experiments, the animals were sacrificed and their brains were removed and stored in a $10 \%$ formalin solution (Fisher). Each brain was sliced at $50 \mu \mathrm{M}$ on a cryostat (Leica), stained (Cresyl Violet), and examined microscopically to confirm probe placement.

\section{Drug Treatments}

The effects of several typical and atypical antipsychotic drugs on ACh efflux in the hippocampus were examined: Haloperidol (1 mg/kg, SC)-Research Biochemicals, Inc. Natick, MA (RBI), thioridazine $(10 \mathrm{mg} / \mathrm{kg}$, $\mathrm{SC})$-Sigma, chlorpromazine $(10 \mathrm{mg} / \mathrm{kg}$, SC)-RBI, as well as olanzapine ( 1 and $3 \mathrm{mg} / \mathrm{kg}$, SC)-Lilly Research Laboratories (LRL), clozapine (5 and $10 \mathrm{mg} / \mathrm{kg}$, SC)$\mathrm{RBI}$, risperidone (1 and $2 \mathrm{mg} / \mathrm{kg}, \mathrm{SC}$ )-RBI, and ziprasidone $(3 \mathrm{mg} / \mathrm{kg}$, SC and IP)-LRL were dissolved in a $5.5 \%$ glucose solution with $10 \mu \mathrm{l}$ of acetic acid. Ziprasidone was administered both IP and SC to minimize possible differences in the pharmacokinetics of the drugs tested, due to the fact that this solution was prepared as a fine suspension. In addition, we examined the effects of selective serotonergic, noradrenergic and dopaminergic receptor compounds on $\mathrm{ACh}$ efflux in the hippocampus: MDL 100,907 (1 mg/ kg, SC)-LRL, prazosin ( $1 \mathrm{mg} / \mathrm{kg}, \mathrm{SC})-\mathrm{RBI}$ and yohimbine $(5 \mathrm{mg} / \mathrm{kg}$, SC)-RBI were dissolved in a 5.5\% glucose solution with $10 \mu \mathrm{l}$ of acetic acid. Ro 04-6790 (10mg/kg, SC)-RBI was dissolved in a $10 \%$ 2-hydroxypropyl- $\beta$-cyclodextrin so- lution (RBI). SB 242,084 (3mg/kg, SC)-LRL was dissolved in a $5 \%$ 2-hydroxypropyl- $\beta$-cyclodextrin solution (RBI) $/ 10 \%$ cremophor EL (Sigma) solution with 10 $\mu \mathrm{l}$ of acetic acid. Both R(+)-8-OH-DPAT $(0.05 \mathrm{mg} / \mathrm{kg})-$ $\mathrm{RBI}$ and raclopride $(1 \mathrm{mg} / \mathrm{kg}$, SC)-RBI were dissolved in saline. The selection of the doses of antipsychotic drugs and selective receptor compounds was based on previous ex vivo, in vivo or other pharmacological studies on receptor occupancy of relevant receptors, e.g. $\mathrm{D}_{2}, 5-\mathrm{HT}_{2}$, muscarinic (Schotte et al. 1996; Zhang and Bymaster 1999; see Discussion). Control animals received injections with the appropriate drug vehicle. The volume of vehicle or drug solution injected for SB 242,084 was $2 \mathrm{ml} / \mathrm{kg}$. The volume of vehicle or drug solution injected was $1 \mathrm{ml} / \mathrm{kg}$ for all other drugs.

\section{Data Analysis}

The corresponding ACh peaks in both the standard solution and the dialysate samples were analyzed using the EZ Chrom Elite software (Scientific Software) program. Microdialysis data were expressed as percent changes (mean \pm S.E.M.) of baseline that was defined as the average absolute value (in pmol/sample) of the four samples before drug injection. Effects of the drug and control treatments were statistically evaluated by 2-way (treatment $\times$ time) analysis of variance (ANOVA) followed by the Bonferroni test for between groups multiple comparisons (Figures 1, 2, 3, 5, 6). Data were also presented as the average mean ( \pm S.E.M.) percent changes over a 2-h period post-injection and analyzed with a 1-way ANOVA followed by the Newman-Keuls test (Figures 4, 7). In all statistical measures, a $p$-value less than .05 was considered significant. Data were statistically evaluated by the Graph Pad Prism program.

\section{RESULTS}

\section{Basal Concentrations of Acetylcholine in Microdialysates from the Hippocampus of the Rat}

Under the present experimental conditions, the basal ACh concentrations in all animals tested ranged from 0.05 to 2.5 $\mathrm{pmol} / \mathrm{sample}$, whereas the average basal values in the groups formed was approximately $0.86 \mathrm{pmol} / \mathrm{sample}$. Between group comparisons of the ACh basal values did not reveal any statistically significant differences.

\section{Effects of Systemic Administration of the Typical Antipsychotic Drugs Haloperidol, Thioridazine, and Chlorpromazine on Extracellular Concentrations of Acetylcholine from the Hippocampus of the Rat}

Vehicle injections did not significantly affect extracellular concentrations of $\mathrm{ACh}$ in the hippocampus (Figure 1). Haloperidol $(1 \mathrm{mg} / \mathrm{kg}, \mathrm{SC})$ and thioridazine $(10 \mathrm{mg} /$ 
A.

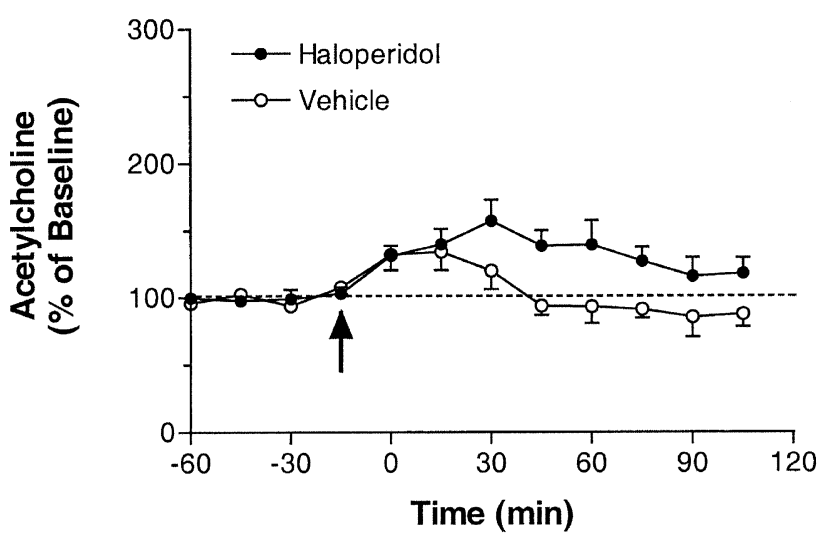

B.

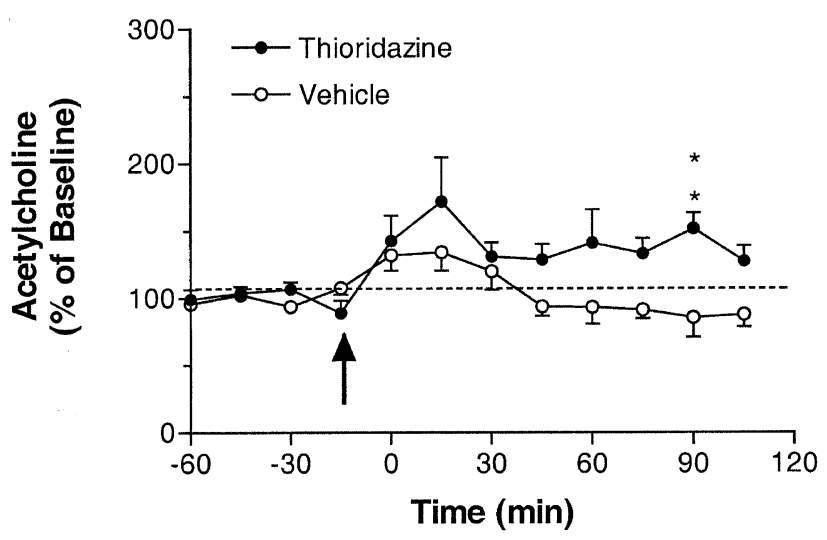

C.

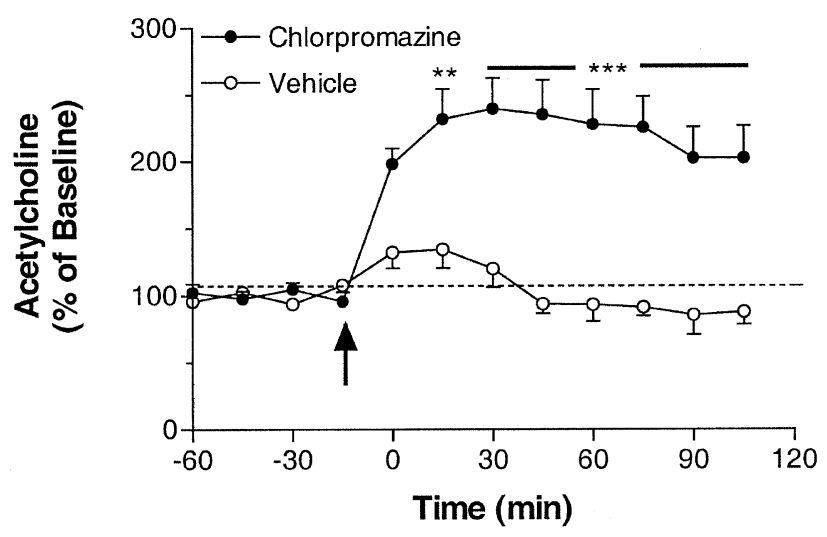

Figure 1. Panel A: Effects of haloperidol $(1 \mathrm{mg} / \mathrm{kg}, \mathrm{SC}, \mathrm{n}=6)$ or vehicle (SC, $n=7$ ) on dialysate concentrations of acetylcholine from the hippocampus. Panel B: Effects of thioridazine $(10 \mathrm{mg} / \mathrm{kg}, \mathrm{SC}, \mathrm{n}=7$ ) or vehicle (SC, $\mathrm{n}=7$ ) on dialysate concentrations of acetylcholine from the hippocampus. Panel $\mathrm{C}$ : Effects of chlorpromazine $(10 \mathrm{mg} / \mathrm{kg}, \mathrm{SC}, \mathrm{n}=7)$ or vehicle (SC, $n=7$ ) on dialysate concentrations of acetylcholine from the hippocampus. Data are presented as mean \pm S.E.M. percent changes of baseline values. ${ }^{* *} p<.01{ }^{* * *} p<.001$ compared with vehicle; arrows indicate last baseline sample. $\mathrm{kg}$, SC) produced about a $50 \%$ increase in ACh release (see Figure 1, Panels A and B). Compared with vehicle, the effect of haloperidol did not attain statistical significance, whereas the effect of thioridazine reached statistical significance $(p<0.01)$ at the $90 \mathrm{~min}$ postinjection interval. Chlorpromazine $(10 \mathrm{mg} / \mathrm{kg}$, SC) produced over $100 \%$ increase in ACh release, which was statistically significant within the 15-105-min postinjection interval as compared with the control group ( $p<.01-.001$, see Figure 1, Panel C).

\section{Effects of Systemic Administration of the Atypical Antipsychotic Drugs Olanzapine and Clozapine on Extracellular Concentrations of Acetylcholine from the Hippocampus of the Rat}

Vehicle injections did not significantly affect extracellular concentrations of $\mathrm{ACh}$ in the hippocampus (Figure

A.

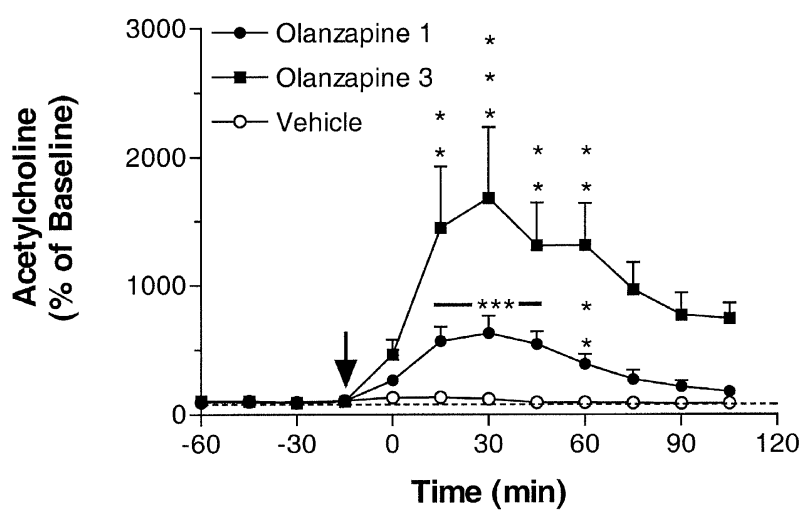

B.

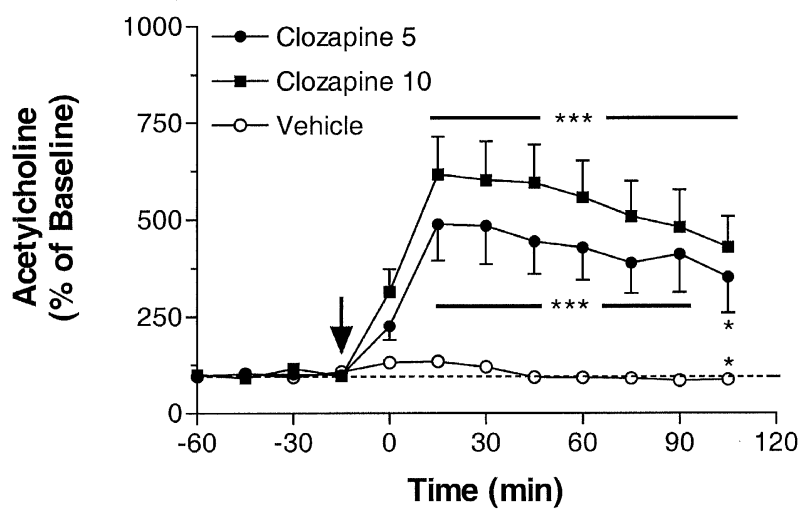

Figure 2. Panel A: Effects of olanzapine $(1 \mathrm{mg} / \mathrm{kg}, \mathrm{SC}, \mathrm{n}=$ 7 and $3 \mathrm{mg} / \mathrm{kg}, \mathrm{SC}, \mathrm{n}=7$ ) or vehicle (SC, $\mathrm{n}=7$ ) on dialysate concentrations of acetylcholine from the hippocampus. Panel B: Effects of clozapine $(5 \mathrm{mg} / \mathrm{kg}, \mathrm{SC}, \mathrm{n}=5$ and $10 \mathrm{mg} /$ $\mathrm{kg}, \mathrm{SC}, \mathrm{n}=5$ ) or vehicle (SC, $\mathrm{n}=7$ ) on dialysate concentrations of acetylcholine from the hippocampus. Data are presented as mean \pm S.E.M. percent changes of baseline values. ${ }^{* *} p<.01,{ }^{* * *} p<.001$ compared with vehicle; arrows indicate last baseline sample. 
A.

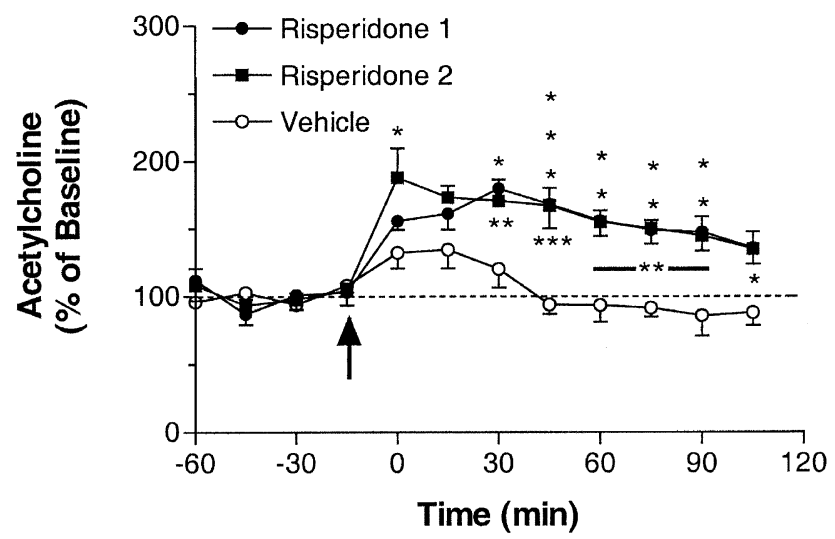

B.

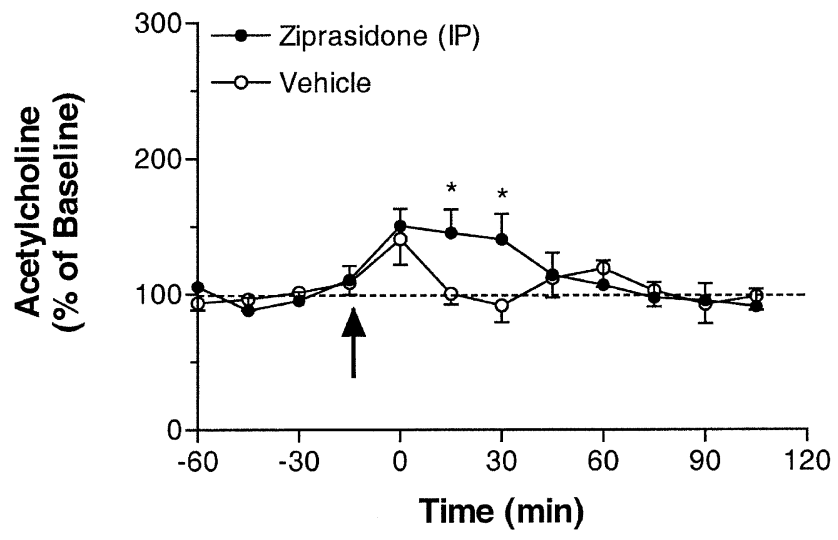

C.

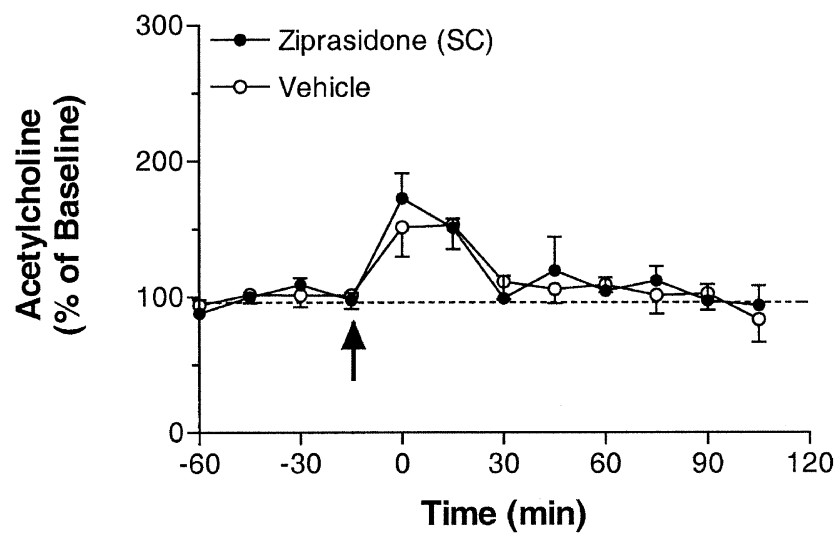

Figure 3. Panel A: Effects of risperidone $(1 \mathrm{mg} / \mathrm{kg}, \mathrm{SC}, \mathrm{n}=5$ and $2 \mathrm{mg} / \mathrm{kg}, \mathrm{SC}, \mathrm{n}=5$ ) or vehicle (SC, $\mathrm{n}=7$ ) on dialysate concentrations of acetylcholine from the hippocampus. Panel B: Effects of ziprasidone ( $3 \mathrm{mg} / \mathrm{kg}, \mathrm{IP}, \mathrm{n}=6$ ) or vehicle (IP, n = 6) on dialysate concentrations of acetylcholine from the hippocampus. Panel C: Effects of ziprasidone $(3 \mathrm{mg} / \mathrm{kg}, \mathrm{SC}, \mathrm{n}=5)$ or vehicle $(\mathrm{SC}, \mathrm{n}=5)$ on dialysate concentrations of acetylcholine from the hippocampus. Data are presented as mean \pm S.E.M. percent changes of baseline values. ${ }^{*} p<.05,{ }^{* *} p<.01,{ }^{* * *} p<.001 \mathrm{com}-$ pared with vehicle; arrows indicate last baseline sample.
2). Olanzapine (1 and $3 \mathrm{mg} / \mathrm{kg}, \mathrm{SC}$ ) produced a marked, dose dependent increase in ACh release, up to $1500 \%$ of baseline (see Figure 2, Panel A). Post-hoc analysis showed that the 1 and $3 \mathrm{mg} / \mathrm{kg}$ dose of olanzapine significantly increased ACh concentrations within the 1560-min postinjection interval as compared with the vehicle control group ( $p<.01-.001$, see Figure 2, Panel A). Clozapine (5 and $10 \mathrm{mg} / \mathrm{kg}$, SC) also increased ACh release by $500 \%$ from basal values (see Figure 2, Panel B). Post-hoc analysis showed that the 5 and $10 \mathrm{mg} / \mathrm{kg}$ concentration of clozapine significantly increased ACh concentrations within the 15-105-min postinjection interval as compared with the vehicle control $(p<.01-.001$, see Figure 2, Panel B).

\section{Effects of Systemic Administration of the Atypical Antipsychotic Drugs Risperidone and Ziprasidone on Extracellular Concentrations of Acetylcholine from the Hippocampus of the Rat}

Vehicle injections did not significantly affect extracellular concentrations of ACh in the hippocampus. Risperidone ( 1 and $2 \mathrm{mg} / \mathrm{kg}, \mathrm{SC}$ ) increased ACh outflow by about $75 \%$ (see Figure 3, Panel A). These effects of risperidone reached statistical significance during various time points postinjection when compared with the vehicle control ( $p<.05-.001$, see Figure 3, Panel A). Ziprasidone $(3 \mathrm{mg} / \mathrm{kg})$ also increased ACh outflow by about $50 \%$ when administered either SC or IP (see Figure 3, Panels B and C). However, this effect reached statistical significance only with the IP administration at the 15-30-min postinjection interval compared with the vehicle control group $(p<.05$, Figure 3, Panel C).

\section{Overall Effects of Typical and Atypical Antipsychotic Drugs on Extracellular Concentrations of Acetylcholine from the Hippocampus of the Rat}

The effects of typical and atypical antipsychotic drugs on ACh concentrations over a 2-h postinjection period are presented in Figure 4. Statistical evaluation of all data depicted in this figure revealed a statistically significant treatment effect $\left(\mathrm{F}_{12,91}=34.68, p<.001\right)$. Posthoc analysis indicated that only olanzapine and clozapine significantly increased the mean overall ACh release compared with the respective vehicle control groups $(p<$ $.01-.001$, see Figure 4).

\section{Effects of Systemic Administration of Selective \\ Receptor Compounds on Extracellular Concentrations of Acetylcholine from the Hippocampus of the Rat}

To determine the underlying mechanism of action of atypical antipsychotic drugs, we examined the effects of 


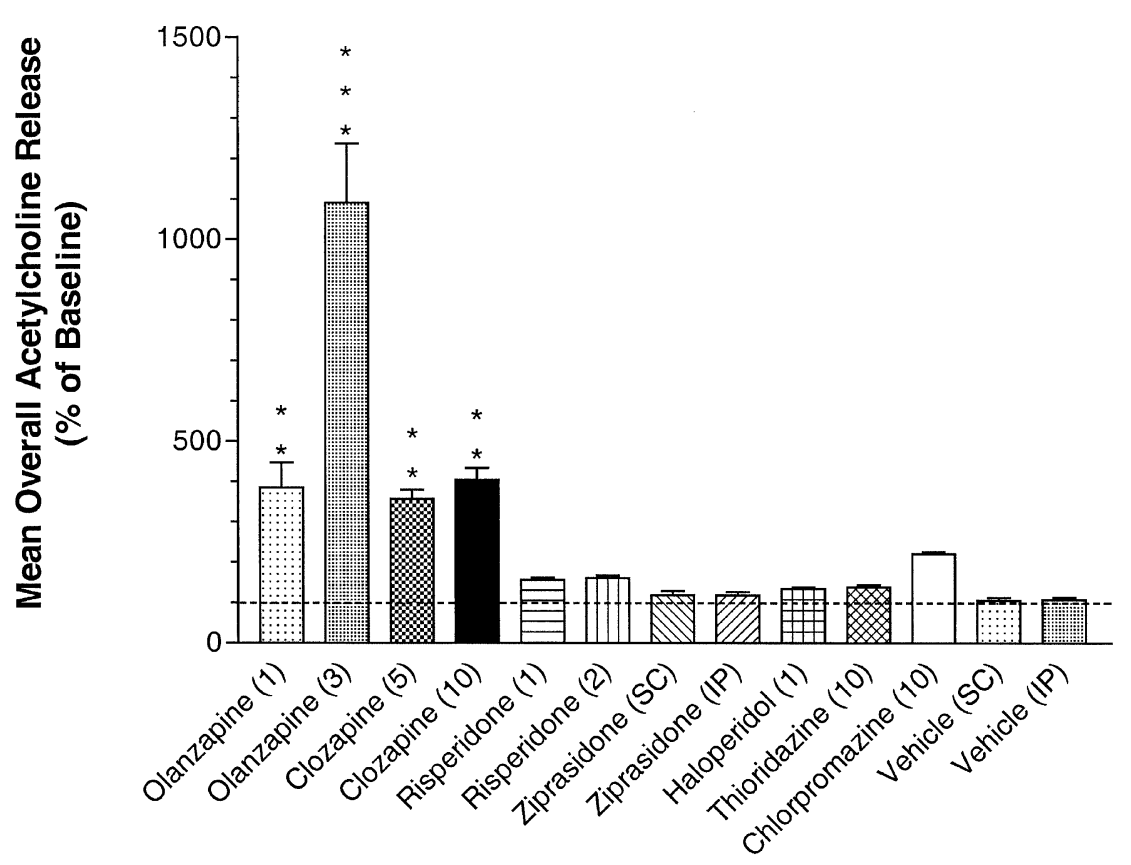

Figure 4. Effects of typical and atypical antipsychotic drugs and their respective vehicle on acetylcholine outflow in the hippocampus. Each bar represents the mean \pm S.E.M. percent change of baseline values over a 2-h postinjection interval. Data were analyzed with a 1-way analysis of variance, followed by the NewmanKeuls test. ${ }^{* *} p<.01,{ }^{* * *} p<.001$ compared with the respective vehicle.

selective compounds for receptors that atypical antipsychotic drugs show relatively high affinity for (Figures 5 and 6). The selective 5- $\mathrm{HT}_{2 \mathrm{~A}}$ receptor antagonist MDL 100,907 (1 mg/kg, SC) increased ACh outflow by about $50 \%$; this effect, however, did not attain statistical significance compared with the vehicle treated group (see Figure 5, Panel A). Similarly, the selective 5- $\mathrm{HT}_{2 \mathrm{C}}$ receptor antagonist SB 242,084 (3 mg/kg, SC) increased ACh outflow by about $60 \%$, an effect that did not reach statistical significance compared with the control group (see Figure 5, Panel B). The selective 5- $\mathrm{HT}_{6}$ receptor antagonist Ro 04-6790 (10 mg/kg, SC) produced a modest $(50 \%)$ increase in ACh outflow; this effect was not statistically different from the action of vehicle (see Figure 5, Panel C). The selective 5- $\mathrm{HT}_{1 \mathrm{~A}}$ agonist $\mathrm{R}(+)-8-\mathrm{OH}-\mathrm{DPAT}$ $(0.05 \mathrm{mg} / \mathrm{kg}$, SC) increased ACh release by about $100 \%$ compared with vehicle controls. Post-hoc analysis showed that $\mathrm{R}(+)-8-\mathrm{OH}-\mathrm{DPAT}$ significantly increased ACh concentrations within the $0-60$-min postinjection interval as compared with the vehicle control $(p<.05-.01$, see Figure 5 , Panel D). The selective $D_{2}$ receptor antagonist raclopride $(1 \mathrm{mg} / \mathrm{kg}, \mathrm{SC})$ increased ACh concentrations by about $50 \%$; this effect reached significance at the $30 \mathrm{~min}$ postinjection interval $(p<.05$, see Figure 6, Panel A). The selective $\alpha_{1}$-adrenergic antagonist prazosin (1mg/ $\mathrm{kg}$, SC) increased ACh outflow by about $50 \%$, an effect that was not statistically different from the actions of vehicle (see Figure 6, Panel B). On the other hand, the $\alpha_{2}$-adrenergic antagonist yohimbine $(5 \mathrm{mg} / \mathrm{kg}, \mathrm{SC})$ induced an about 50\% increase in ACh efflux that lasted the entire postinjection interval, attaining statistical significance at several time points when compared with vehicle control $(p<.01$, Figure 6 , Panel C).

\section{Overall Effects of Selective Receptor Compounds on Extracellular Concentrations of Acetylcholine from the Hippocampus of the Rat}

The effects of selective receptor compounds on ACh concentrations over a 2-h postinjection period are presented in Figure 7. Statistical evaluation of all data depicted in this figure revealed a statistically significant treatment effect $\left(\mathrm{F}_{10,77}=5.23, p<.001\right)$. Post-hoc analysis indicated that only the selective $\alpha_{2}$-adrenergic antagonist yohimbine and the selective $5-\mathrm{HT}_{1 \mathrm{~A}}$ agonist $\mathrm{R}(+)$ 8-OH-DPAT significantly increased the mean overall ACh release compared with the respective vehicle control groups $(p<.05$, see Figure 7$)$.

\section{DISCUSSION}

The major finding of the present study is that olanzapine and clozapine increase ACh outflow in the hippocampus of the rat to a greater extent than other antipsychotic drugs tested, either typical (haloperidol, chlorpromazine, thioridazine) or atypical (risperidone, ziprasidone). In addition, selective action at only one of the monoaminergic receptor sites affected by antipsychotic drugs, e.g. $\mathrm{D}_{2}, 5-\mathrm{HT}_{2 \mathrm{~A}}, 5-\mathrm{HT}_{2 \mathrm{C}}, 5-\mathrm{HT}_{6}, 5-\mathrm{HT}_{1 \mathrm{~A}}, \alpha_{1}$ and $\alpha_{2}$-adrenoceptors, does not appear to exclusively account for the marked increases in hippocampal ACh efflux observed with both olanzapine and clozapine. The increased release of ACh in the hippocampus could contribute to the improvement of cognitive functions observed with some atypical antipsychotic drug use, particularly with olanzapine, in schizophrenia (Purdon et al. 2000; Cuesta et al. 2001). In clinical studies, both 
A.

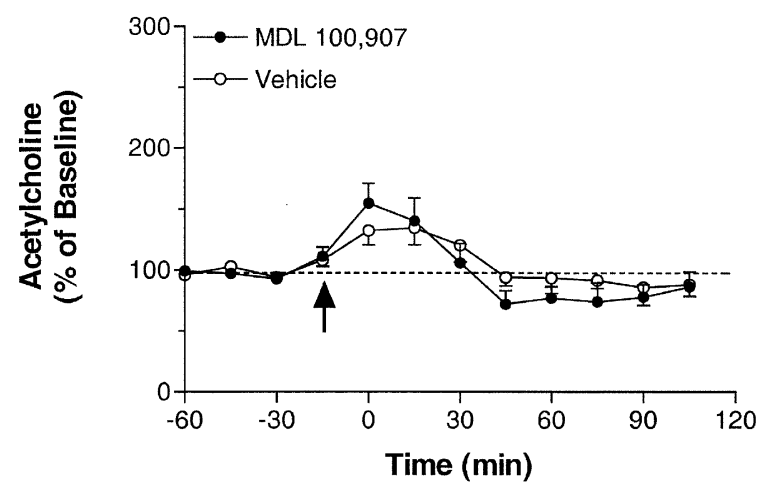

B.

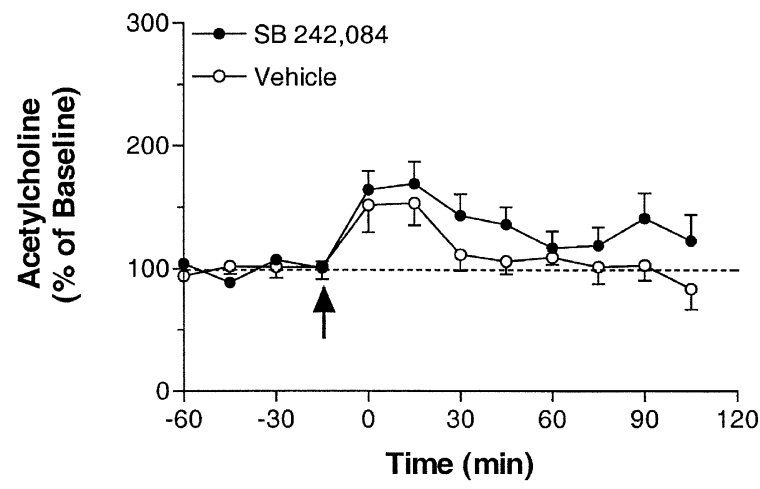

C.

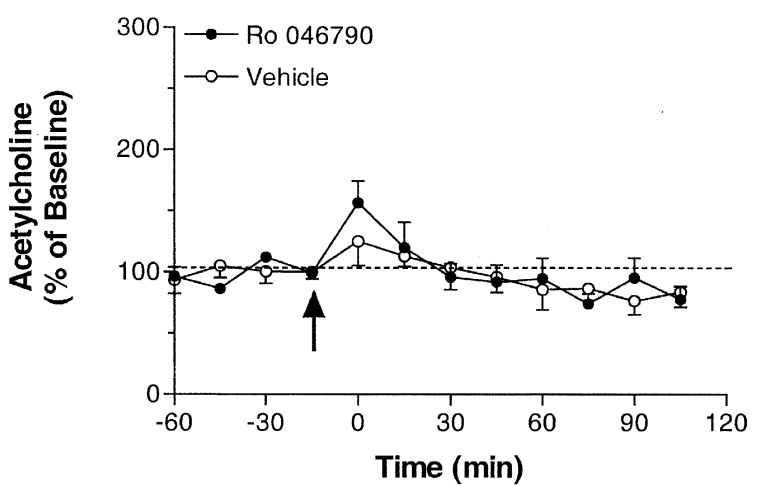

D.

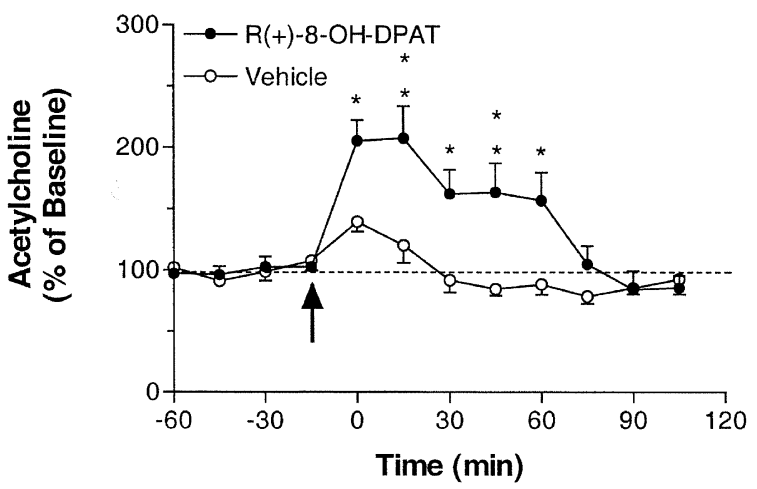

Figure 5. Panel A: Effects of MDL 100, $907(1 \mathrm{mg} / \mathrm{kg}, \mathrm{SC}, \mathrm{n}=7)$ or vehicle $(\mathrm{SC}, \mathrm{n}=7)$ on dialysate concentrations of acetylcholine from the hippocampus. Panel B: Effects of SB 242,084 $(3 \mathrm{mg} / \mathrm{kg}, \mathrm{SC}, \mathrm{n}=6)$ or vehicle $(\mathrm{SC}, \mathrm{n}=5)$ on dialysate concentrations of acetylcholine from the hippocampus. Panel C: Effects of Ro 04-6790 $(10 \mathrm{mg} / \mathrm{kg}, \mathrm{SC}, \mathrm{n}=7)$ or vehicle $(\mathrm{SC}, \mathrm{n}=$ 6) on dialysate concentrations of acetylcholine from the hippocampus. Panel D: Effects of R(+)-8-OH-DPAT $(0.05 \mathrm{mg} / \mathrm{kg}, \mathrm{SC}$, $\mathrm{n}=6$ ) or vehicle (SC, $\mathrm{n}=6$ ) on dialysate concentrations of acetylcholine from the hippocampus. Data are presented as mean \pm S.E.M. percent changes of baseline values. ${ }^{*} p<.05,{ }^{* *} p<.01,{ }^{* * *} p<.001$ compared with vehicle; arrows indicate last baseline sample.

olanzapine and clozapine, and to some extent risperidone, have been found to be beneficial in improving procedural learning tasks; these cognitive improvements have not been apparent with haloperidol treatment (Purdon et al. 2000; Purdon 2000).

All experiments in the present study were conducted in the presence of $0.3 \mu \mathrm{M}$ of the AChesterase inhibitor neostigmine in the perfusion solution. This concentration is within the range, i.e. $0.1-1 \mu \mathrm{M}$, regularly used in most microdialysis studies to decrease elimination and increase detectability of $\mathrm{ACh}$ in the dialysate. It has become increasingly apparent though that inclusion of an AChesterase inhibitor in the perfusion solution may affect the obtained pharmacological responses both quantitatively and qualitatively. This has been clearly illustrated by studying the effects of muscarinic receptor antagonists and AChesterase inhibitors on ACh outflow in the brain (Kawashima et al. 1991; Messamore et al. 1993a, 1993b; Moor et al. 1998), and on the effects of dopaminergic agents on striatal ACh efflux (DeBoer and Abercrombie 1996; Acquas and Fibiger 1998). On the other hand, physiologically relevant ACh responses appear to be independent of the concentration of AChesterase inhibitors in the perfusion medium (Moor et al. 1998; Himmelheber et al. 1998). To the extent that the effects of the antipsychotic drugs tested on hippocampal ACh are not mediated through actions at muscarinic or dopaminergic receptors (see below), it is inferred that the detected differences are not skewed by the presence of an AChesterase inhibitor in the perfusate. In fact, preliminary studies in our laboratory have revealed that at least the effects of olanzapine on $\mathrm{ACh}$ 
A.

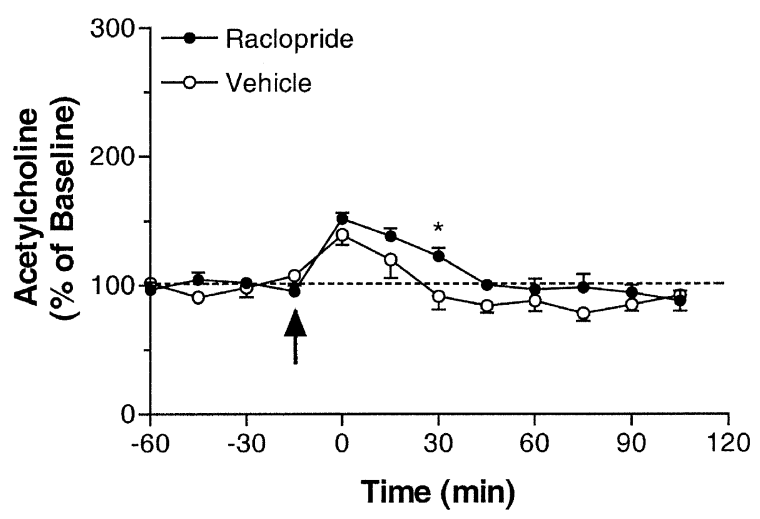

B.

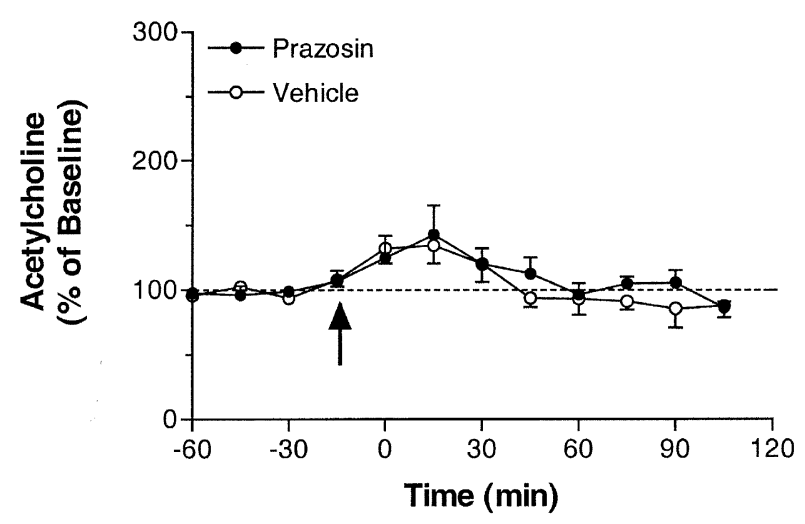

C.

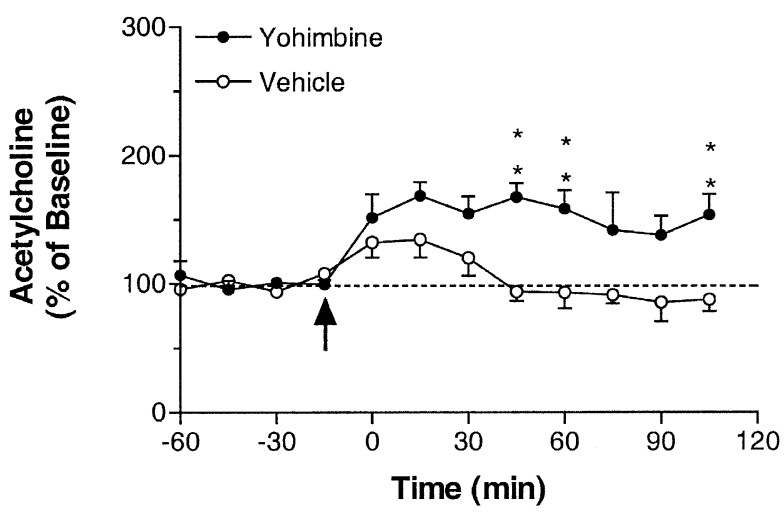

Figure 6. Panel A: Effects of raclopride $(1 \mathrm{mg} / \mathrm{kg}, \mathrm{SC}, \mathrm{n}=$ 9) or vehicle ( $\mathrm{SC}, \mathrm{n}=6)$ on dialysate concentrations of acetylcholine from the hippocampus. Panel B: Effects of prazosin $(1 \mathrm{mg} / \mathrm{kg}, \mathrm{SC}, \mathrm{n}=5)$ or vehicle (SC, $\mathrm{n}=7$ ) on dialysate concentrations of acetylcholine from the hippocampus. Panel C: Effects of yohimbine $(5 \mathrm{mg} / \mathrm{kg}, \mathrm{SC}, \mathrm{n}=6)$ or vehicle $(\mathrm{SC}, \mathrm{n}=7)$ on dialysate concentrations of acetylcholine from the hippocampus. Data are presented as mean \pm S.E.M. percent changes of baseline values. ${ }^{*} p<.05$, ${ }^{* *} p<.01$ compared with vehicle; arrows indicate last baseline sample. efflux in the hippocampus are independent of the concentration of neostigmine in the perfusion solution. Whether this is unequivocally the case for the effects of other antipsychotic drugs on ACh outflow in hippocampus and in other regions of the brain remains to be shown.

The selection of doses used for both typical and atypical antipsychotic drugs tested in this study was based on previous ex vivo and in vivo receptor binding studies (Schotte et al. 1996; Zhang and Bymaster 1999). For example, the $\mathrm{ID}_{50}$ (dose required to block $50 \%$ of the radioligand binding) values of olanzapine, risperidone, haloperidol and chlorpromazine for occupying D2 receptors in the brain of the rat are 0.6, 0.2, 0.12 and 0.5 $\mathrm{mg} / \mathrm{kg}$, respectively (Zhang and Bymaster 1999). Similarly, the occupancy of $5-\mathrm{HT}_{2}$ receptors is estimated to be greater than $50 \%$ with the doses of the atypical antipsychotic drugs used, in view of the fact that the $\mathrm{ID}_{50}$ values are $0.15,2.2$ and $0.1 \mathrm{mg} / \mathrm{kg}$ for olanzapine, clozapine and risperidone, respectively (Zhang and Bymaster 1999). Ziprasidone was tested at the $3 \mathrm{mg} / \mathrm{kg}$ dose that achieves approximately a 70\% total receptor occupancy for the $5-\mathrm{HT}_{2 \mathrm{~A}}$ receptor subtype and a $20 \%$ total receptor occupancy for the $\mathrm{D}_{2}$ receptors (Schotte et al. 1996; Zhang and Bymaster 1999). In addition, the $3 \mathrm{mg} / \mathrm{kg}$ dose of ziprasidone was selected in the present study, because doses in this range are usually used in other biochemical and pharmacological animal studies (see e.g. Rollema et al. 2000). Thus, it is estimated that the doses of the antipsychotic compounds tested result in a greater than $50 \%$ occupancy of $\mathrm{D}_{2}, 5-\mathrm{HT}_{2}$, or both receptors in the brain. Analogously, the doses of the receptor selective compounds used in the present study were selected on the basis of ex vivo and in vivo occupancy data for the respective receptors, if available (Schotte et al. 1996; Zhang and Bymaster 1999). In the absence of binding data, data from other pharmacological and biochemical studies revealing activity at the respective receptors were used to select relevant doses (see e.g. Nomikos et al. 1992; Andersson et al. 1994, 1995; Nomikos et al. 1994; Acquas et al. 1998; Bentley et al. 1999; Grottick et al. 2000; Marcus et al. 2000). For example, based on a number of previously published preclinical data (Nomikos et al. 1994; Andersson et al. 1995; Acquas and Fibiger 1998), it is estimated that full occupancy and blockade of D2 receptors in the brain is achieved by the dose of raclopride used.

The results of the present study show that the atypical antipsychotic drugs olanzapine and clozapine increase ACh efflux in the hippocampus to a greater extent than the classical neuroleptics haloperidol, thioridazine and chlorpromazine, and the atypical antipsychotic drugs risperidone and ziprasidone. Previous microdialysis studies have shown that clozapine increases $\mathrm{ACh}$ release in the prefrontal cortex and the nucleus accumbens to a greater extent than classical 


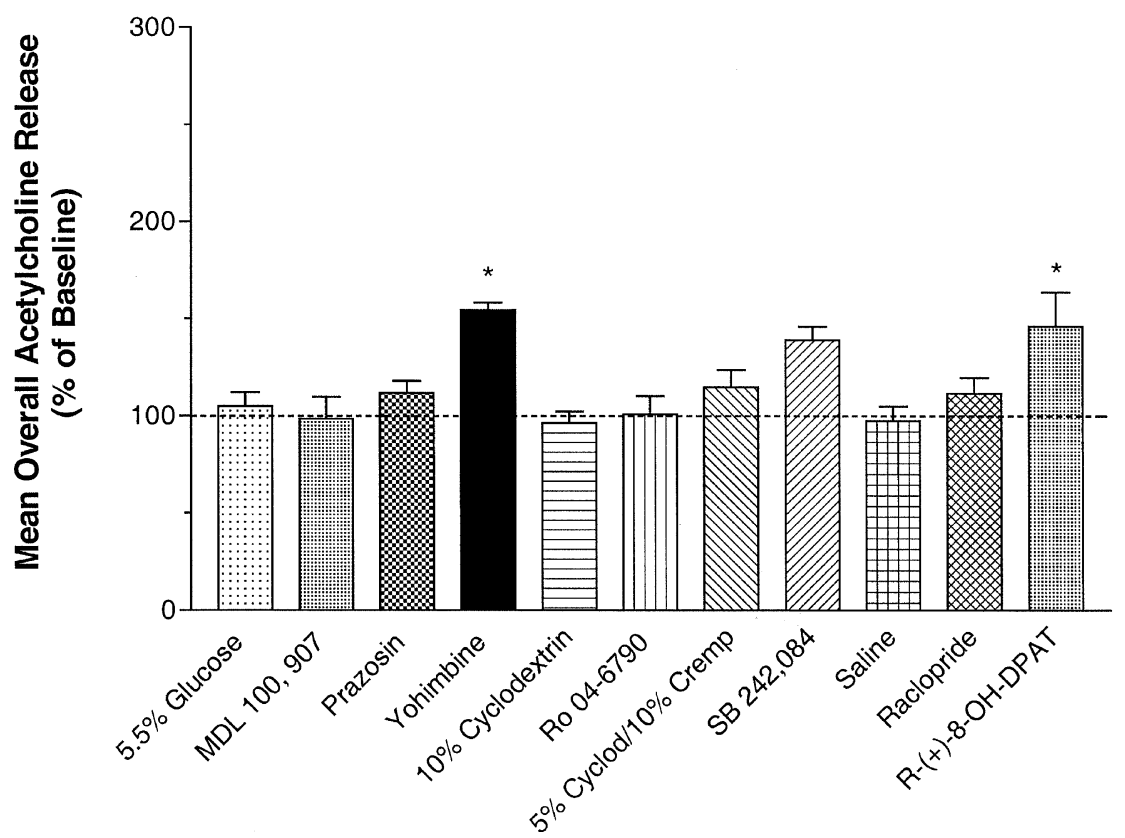

Figure 7. Effects of receptor selective compounds and their respective vehicle on acetylcholine outflow in the hippocampus. Each bar represents the mean \pm S.E.M. percent change of baseline values over a 2-h postinjection interval. Data were analyzed with an 1-way analysis of variance, followed by the Newman-Keuls test; ${ }^{*} p<.05$ compared with the respective vehicle. neuroleptics (Parada et al. 1997; Moore et al. 1999), whereas clozapine and other antipsychotic drugs studied variably affect ACh release in the striatum (Imperato et al. 1993; Ueda et al. 1995; DeBoer and Abercrombie 1996; Ikarashi et al. 1997; Parada et al. 1997; Moore et al. 1999). The effect of clozapine on ACh release appeared to be more pronounced in the prefrontal cortex than in the nucleus accumbens or the striatum (Parada et al. 1997). The present results indicate that effective antipsychotic drugs are clearly differentiated on the basis of their effects on ACh outflow in the hippocampus, although the reasons for this differential response between olanzapine and clozapine in one hand and all the other antipsychotic drugs in the other cannot be easily understood. Differences in the ability of the tested antipsychotic drugs to affect $D_{2}$ receptors could not entirely account for the observed differences in ACh outflow, because all the antipsychotic drugs tested (with the exception of ziprasidone and clozapine) block $\mathrm{D}_{2}$ receptors to a considerable degree (see above). In addition, full $\mathrm{D}_{2}$ receptor blockade achieved by raclopride results only in a modest increase in hippocampal $\mathrm{ACh}$ (this study). These results are in agreement with those of earlier microdialysis studies testing the effects of other $\mathrm{D}_{2}$ receptor antagonists on ACh efflux in the brain (Imperato et al. 1993; Russi et al. 1993; DeBoer and Abercrombie 1996; Ikarashi et al. 1997; Acquas and Fibiger 1998; Moore et al. 1999). Similarly, under the present experimental conditions, administration of olanzapine, clozapine, risperidone and ziprasidone results in a considerable blockade of $5-\mathrm{HT}_{2}$ receptors (see above). Thus, differences in the degree of blockade of $5-\mathrm{HT}_{2}$ receptors elicited by the antipsychotic drugs tested could not solely account for the observed differential ACh re- sponses. In consonance with this notion, administration of the selective 5- $\mathrm{HT}_{2 \mathrm{~A}}$ and $5-\mathrm{HT}_{2 \mathrm{C}}$ receptor antagonists, at pharmacologically relevant doses, failed to affect significantly ACh outflow in the hippocampus (this study). Similar results have previously been reported with other $5-\mathrm{HT}_{2}$ receptor antagonists, e.g. ketanserin, ritanserin, and mesulergine, which exhibit varying degrees of $5-\mathrm{HT}_{2 \mathrm{~A}}$ vs. 5- $\mathrm{HT}_{2 \mathrm{C}}$ receptor selectivity (Hirano et al. 1995; Consolo et al. 1996; Zhelyazkova-Savova et al. 1999). Interestingly, both clozapine and olanzapine, in contrast to other antipsychotic drugs tested, appear to show high affinity for the 5- $\mathrm{HT}_{6}$ receptors (Roth et al. 1994; Bymaster et al. 1999), and 5- $\mathrm{HT}_{6}$ receptor antagonists purportedly increase cholinergic function in the brain (Bentley et al. 1999). Accordingly, selective action at the $5-\mathrm{HT}_{6}$ receptors could account for the pronounced effects of clozapine and olanzapine on hippocampal ACh outflow, as compared with the other antipsychotic drugs. However, administration of the $5-\mathrm{HT}_{6}$ receptor antagonist Ro 04-6790 did not significantly affect ACh efflux in the hippocampus, a finding that argues against a significant involvement of 5- $\mathrm{HT}_{6}$ receptors in the detected differential ACh responses. It is noteworthy that antipsychotic drugs exhibit varying degrees of antagonism at $\alpha_{1}$ adrenoceptors (Cohen and Lipinski 1986). In view, however of the present and earlier (Acquas et al. 1998) findings that the $\alpha_{1}$ adrenoceptor antagonist prazosin failed to affect hippocampal ACh concentrations, it is concluded that $\alpha_{1}$ adrenoceptor antagonism does not significantly contribute to the displayed differences in the hippocampal ACh responses. On the other hand, it has been well established that $5-\mathrm{HT}_{1 \mathrm{~A}}$ receptor agonistic action results in a significant increase in ACh outflow in the brain (Izumi et al. 1994; Wilkinson et al. 1994). This 
receptor activity might be of importance for the neurobiological effects of, primarily, clozapine and ziprasidone (Rollema et al. 1997, 2000). Similarly, it is unequivocally recognized that $\alpha_{2}$ adrenoceptor antagonists increase ACh efflux in the brain (Tellez et al. 1997; Acquas et al. 1998), and that $\alpha_{2}$ adrenoceptor antagonism may underlie some of the central actions of clozapine, risperidone, and to a lesser extent of olanzapine (Hertel et al. 1999a,b). Notwithstanding the fact that we also found significant increases in ACh concentrations in the hippocampus in response to the 5- $\mathrm{HT}_{1 \mathrm{~A}}$ receptor agonist R-8-OH-DPAT $(+100 \%)$ and the $\alpha_{2}$ adrenoceptor antagonist yohimbine $(+60 \%)$, the marked increase in hippocampal ACh after olanzapine (+1400\%) cannot be attributed in its entirety to these receptor actions. Admittedly though, $5-\mathrm{HT}_{1 \mathrm{~A}}$ receptor agonistic action and $\alpha_{2}$ adrenoceptor antagonistic activity may play an important role in the stimulatory effects of clozapine and risperidone, respectively, on ACh outflow in the hippocampus.

Previous microdialysis studies have shown that administration of non-selective muscarinic receptor antagonists causes marked increases in ACh concentrations in the brain (Day et al. 1991; Kawashima et al. 1991; Quirion et al. 1994; Moor et al. 1998). These effects are mainly attributed to $M_{2}$ receptor antagonism, whereas the involvement of $\mathrm{M}_{1}$ or other muscarinic receptor activity is less obvious (Billard et al. 1995; Stillman et al. 1996). In this regard, it appears that $M_{1}$ receptor agonists invariably augment $\mathrm{ACh}$ release in the brain (Ogane et al. 1990; Murakami et al. 1996; Suzuki et al. 1998). Thus, $M_{1}$ receptor antagonistic action may even counteract the increase in $\mathrm{ACh}$ release mediated via $\mathrm{M}_{2}$ receptor antagonism. Of the antipsychotic compounds tested, olanzapine, clozapine and thioridazine show comparable affinities for the $\mathrm{M}_{1}$ and $\mathrm{M}_{2}$ receptors in the nM range in vitro (Bolden et al. 1992; Bymaster et al. 1996; Arnt and Skarsfeldt 1998). Nevertheless, only olanzapine and thioridazine appear to function as full antagonists at both muscarinic receptors (Bolden et al. 1992; Bymaster et al. 1996). Importantly, based on in vivo binding data (Zhang and Bymaster 1999), the estimated occupancy of muscarinic receptors after olanzapine and clozapine is less than $10 \%$, whereas that after thioridazine is somewhat higher, at the doses tested. Yet, olanzapine and clozapine markedly increase hippocampal ACh outflow, sharply contrasting the modest effects observed after thioridazine. In fact, even a much higher dose of thioridazine $(30 \mathrm{mg} / \mathrm{kg})$ failed to increase ACh outflow further (Southall et al. unpublished observations). Additionally, other pharmacological studies have provided substantial evidence in support of the notion that the muscarinic component of the activity of either olanzapine or clozapine in vivo is at best minimal (Arnt and Skarsfeldt 1998; Bymaster and Falcone 2000). Taken together, it appears likely that mus- carinic receptor antagonism does not solely mediate the marked effects of olanzapine and clozapine on ACh efflux in the hippocampus, although such an involvement cannot understandably be excluded.

In summary, we have demonstrated by using in vivo microdialysis, that the atypical antipsychotic compounds, olanzapine and clozapine, increase $\mathrm{ACh}$ in the hippocampus to a far greater extent than other typical and atypical antipsychotic drugs. Selective receptor activities at $5-\mathrm{HT}_{2 \mathrm{~A}}, 5-\mathrm{HT}_{6}, 5-\mathrm{HT}_{2 \mathrm{C}}, \mathrm{D}_{2}$, and $\alpha_{1}$-adrenergic receptors most likely are not solely responsible for the increases in hippocampal ACh efflux observed with either olanzapine or clozapine. On the other hand, $\alpha_{2}-$ adrenergic receptor antagonism and $5-\mathrm{HT}_{1 \mathrm{~A}}$ agonistic action may be of some importance to the stimulatory effect of clozapine on ACh efflux in the hippocampus. To this end, it cannot be excluded that combinations of several receptor-mediated mechanisms including those studied herein are responsible for the marked effects of olanzapine and clozapine on $\mathrm{ACh}$ release. In this regard, the role of other receptor systems, e.g. $\mathrm{D}_{1}, \mathrm{D}_{4}$, histaminergic, 5- $\mathrm{HT}_{7}$, in the detected, drug selective action of clozapine and olanzapine on hippocampal ACh remains to be elucidated. Ultimately, the unique multireceptor acting profiles that clozapine and olanzapine exhibit (Bymaster et al. 2000) may be responsible for their marked effects on cholinergic neurotransmission in the brain. This distinguishing feature may in turn be important for the beneficial effects of these atypical antipsychotic agents in cognitive function in schizophrenia.

\section{ACKNOWLEDGMENTS}

We thank Frank Bymaster and David Nelson for their scientific guidance in all aspects of this study.

\section{REFERENCES}

Acquas E, Fibiger HC (1998): Dopaminergic regulation of striatal acetylcholine release: the critical role of acetylcholinesterase inhibition. J Neurochem 70:1088-1093

Acquas E, Wilson C, Fibiger HC (1998): Pharmacology of sensory stimulation-evoked increases in frontal cortical acetylcholine release. Neuroscience 85:73-83

Andersson JL, Marcus M, Nomikos GG, Svensson TH (1994): Prazosin modulates the changes in firing pattern and transmitter release induced by raclopride in the mesolimbic, but not in the nigrostriatal dopaminergic system. NS Arch Pharmacol 349:236-243

Andersson JL, Nomikos GG, Marcus M, Hertel P, Mathe JM, Svensson TH (1995): Ritanserin potentiates the stimulatory effects of raclopride on neuronal activity and dopamine release selectivity in the mesolimbic dopaminergic system. NS Arch Pharmacol 352:374-385 
Arnt J, Skarsfeldt T (1998): Do novel antipsychotics have similar pharmacological characteristics? A review of the evidence. Neuropsychopharmacology 18:63-101

Bentley JC, Bourson A, Boess FG, Fone KC, Marsden CA, Petit N, Sleight AJ (1999): Investigation of stretching behaviour induced by the selective 5-HT6 receptor antagonist, Ro 04-6790, in rats. Br J Pharmacol 126:1537-1542

Billard W, Binch H 3rd, Crosby G, McQuade RD (1995): Identification of the primary muscarinic autoreceptor subtype in rat striatum as M2 through a correlation of in vivo microdialysis and in vitro receptor binding data. J Pharmacol Exp Ther 273:273-279

Bolden C, Cusack B, Richelson E (1992): Antagonism by antimuscarinic and neuroleptic compounds at the five cloned human muscarinic cholinergic receptors expressed in Chinese hamster ovary cells. J Pharmacol Exp Ther 260:576-580

Breier A (1999): Cognitive deficit in schizophrenia and its neurochemical basis. Br J Psychiatry (Suppl 37):16-18

Bymaster FP, Calligaro DO, Falcone JF, Marsh RD, Moore NA, Tye NC, Seeman P, Wong DT (1996): Radioreceptor binding profile of the atypical antipsychotic olanzapine. Neuropsychopharmacology 14:87-96

Bymaster F, Perry KW, Nelson DL, Wong DT, Rasmussen K, Moore NA, Calligaro DO (1999): Olanzapine: a basic science update. Br J Psychiatry 37:36-40

Bymaster FP, Falcone JF (2000): Decreased binding affinity of olanzapine and clozapine for human muscarinic receptors in intact clonal cells in physiological medium. Eur J Pharmacol 390:245-248

Bymaster FP, Breier A, Tollefson GD, Herrera JM, Tran PV (2000): Olanzapine belongs to a new multi-acting-receptor-targeted-antipsychotic (MARTA) class of antipsychotics. In Tran PV, Tye N, Herrera JM, Breier A, Tollefson GD (eds), Olanzapine (Zyprexa): A Novel Antipsychotic. Philadelphia, Lippincott Williams \& Wilkins Healthcare, pp ix-xi

Cohen BM, Lipinski JF (1986): In vivo potencies of antipsychotic drugs in blocking alpha 1 noradrenergic and dopamine D2 receptors: implications for drug mechanisms of action. Life Sci 39:2571-2580

Consolo S, Arnaboldi S, Ramponi S, Nannini L, Ladinsky H, Baldi G (1996): Endogenous serotonin facilitates in vivo acetylcholine release in rat frontal cortex through 5-HT 1B receptors. J Pharmacol Exp Ther 277:823-830

Cuesta MJ, Peralta V, Zarzuela A (2001): Effects of olanzapine and other antipsychotics on cognitive function in chronic schizophrenia: a longitudinal study. Schizophr Res 48:17-28

Day J, Damsma G, Fibiger HC (1991): Cholinergic activity in the rat hippocampus, cortex and striatum correlates with locomotor activity: an in vivo microdialysis study. Pharmacol Biochem Behav 38:723-729

DeBoer P, Abercrombie ED (1996): Physiological release of striatal acetylcholine in vivo: modulation by D1 and D2 dopamine receptor subtypes. J Pharmacol Exp Ther 277:775-783

Eichenbaum H, Dudchenko P, Wood E, Shapiro M, Tanila H (1999): The hippocampus, memory, and place cells: is it spatial memory or a memory space? Neuron 23:209-226
Grottick AJ, Fletcher PJ, Higgins GA (2000): Studies to investigate the role of $5-\mathrm{HT}(2 \mathrm{C})$ receptors on cocaine-and food-maintained behavior. J Pharmacol Exp Ther 295:1183-1191

Hertel P, Fagerquist MV, Svensson TH (1999a): Enhanced cortical dopamine output and antipsychotic-like effects of raclopride by alpha2 adrenoceptor blockade. Science 5437:105-107

Hertel P, Nomikos GG, Svensson TH (1999b): The antipsychotic drug risperidone interacts with auto- and hetero receptors regulating serotonin output in the rat frontal cortex. Neuropharmacology 38:1175-1184

Himmelheber AM, Fadel J, Sarter M, Bruno JP (1998): Effects of local cholinesterase inhibition on acetylcholine release assessed simultaneously in prefrontal and frontoparietal cortex. Neuroscience 86:949-957

Hirano H, Day J, Fibiger HC (1995): Serotonergic regulation of acetylcholine release in rat frontal cortex. J Neurochem 65:1139-1145

Ikarashi Y, Takahashi A, Ishimaru H, Arai T, Maruyama Y (1997): Relations between the extracellular concentrations of choline and acetylcholine in rat striatum. J Neurochem 69:1246-1251

Imperato A, Obinu MC, Casu MA, Mascia MS, Dazzi L, Gessa GL (1993): Evidence that neuroleptics increase striatal acetylcholine release through stimulation of dopamine D1 receptors. J Pharmacol Exp Ther 266:557-562

Izumi J, Washizuka M, Miura N, Hiraga Y, Ikeda Y (1994): Hippocampal serotonin 5- HT1A receptor enhances acetylcholine release in conscious rats. J Neurochem 62:1804-1808

Kawashima K, Hayakawa T, Kashima Y, Suzuki T, Fujimoto K, Oohata H (1991): Determination of acetylcholine release in the striatum of anesthetized rats using in vivo microdialysis and a radioimmunoassay. J Neurochem $57: 882-887$

Kinon BJ, Lieberman JA (1996): Mechanisms of action of atypical antipsychotic drugs: a critical analysis. Psychopharmacology 124:2-34

Leysen JE, Janssen PM, Gommeren W, Wynants J, Pauwels PJ, Janssen PA (1992): In vitro and in vivo receptor binding and effects on monoamine turnover in rat brain regions of the novel antipsychotics risperidone and ocaperidone. Mol Pharmacol 41:494-508

Marcus MM, Nomikos GG, Svensson TH (2000): Effects of atypical antipsychotic drugs on dopamine output in the shell and core of the nucleus accumbens: role of 5-HT(2A) and alpha(1)-adrenoceptor antagonism. Eur Neuropsychopharmacol 10:245-253

Meltzer HY, Matsubara S, Lee JC (1989): Classification of typical and atypical antipsychotic drugs on the basis of dopamine D-1, D-2 and serotonin2 pKi values. J Pharmacol Exp Ther 251:238-246

Meltzer HY, McGurk SR (1999): The effects of clozapine, risperidone, and olanzapine on cognitive function in schizophrenia. Schizophr Bull 25:233-255

Messamore E, Ogane N, Giacobini E (1993a): Cholinesterase inhibitor effects on extracellular acetylcholine in rat striatum. Neuropharmacology 32:291-296

Messamore E, Warpman U, Williams E, Giacobini E (1993b): Muscarinic receptors mediate attenuation of extracellu- 
lar acetylcholine levels in rat cerebral cortex after cholinesterase inhibition. Neurosci Lett 158:205-208

Moor E, Schirm E, Jacso J, Westerink BH (1998): Effects of neostigmine and atropine on basal and handlinginduced acetylcholine output from ventral hippocampus. Neuroscience 82:819-825

Moore H, Fadel J, Sarter M, Bruno JP (1999): Role of accumbens and cortical dopamine receptors in the regulation of cortical acetylcholine release. Neuroscience 88:811-822

Murakami Y, Matsumoto K, Ohta H, Watanabe H (1996): Effects of oxotremorine and pilocarpine on striatal acetylcholine release as studied by brain dialysis in anesthetized rats. Gen Pharmacol 27:833-836

Nomikos GG, Arborelius L, Svensson TH (1992): The novel 5-HT1A receptor antagonist (S)-UH-301 prevents (R)8-OH-DPAT-induced decrease in interstitial concentrations of serotonin in the rat hippocampus. Eur J Pharmacol 216:373-378

Nomikos GG, Iurlo M, Andersson JL, Kimura K, Svensson TH (1994): Systemic administration of amperozide, a new atypical antipsychotic drug, preferentially increases dopamine release in the rat medial prefrontal cortex. Psychopharmacology 115:147-156

Ogane N, Takada Y, Iga Y, Kawanishi G, Mizobe F (1990): Effects of a M1 muscarinic receptor agonist on the central cholinergic system, evaluated by brain microdialysis. Neurosci Lett 114:95-100

Parada MA, Hernandez L, Puig de Parada M, Rada P, Murzi E (1997): Selective action of acute systemic clozapine on acetylcholine release in the rat prefrontal cortex by reference to the nucleus accumbens and striatum. J Pharmacol Exp Ther 281:582-588

Paxinos G, Watson C (1986): The rat brain in stereotaxic coordinates. San Diego, Academic Press

Purdon SE (2000): Measuring neuropsychological change in schizophrenia with novel antipsychotic medications. J Psychiatry Neurosci 25:108-116

Purdon SE, Jones BD, Stip E, Labelle A, Addington D, David SR, Breier A, Tollefson GD (2000): Neuropsychological change in early phase schizophrenia during 12 months of treatment with olanzapine, risperidone, or haloperidol. Arch Gen Psychiatry 57:249-258

Quirion R, Richard J, Wilson A (1994): Muscarinic and nicotinic modulation of cortical acetylcholine release monitored by in vivo microdialysis in freely moving adult rats. Synapse 17:92-100

Remington G, Kapur S (2000): Atypical antipsychotics: are some more atypical than others? Psychopharmacology 148:3-15
Rollema H, Lu Y, Schmidt AW, Zorn SH (1997): Clozapine increases dopamine release in prefrontal cortex by 5-HT1A receptor activation. Eur J Pharmacol 338:R3-5

Rollema H, Lu Y, Schmidt AW, Sprouse JS, Zorn SH (2000): 5 -HT(1A) receptor activation contributes to ziprasidone-induced dopamine release in the rat prefrontal cortex. Biol Psychiatry 48:229-237

Roth BL, Craigo SC, Choudhary MS, Uluer A, Monsma FJ Jr, Shen Y, Meltzer HY, Sibley DR (1994): Binding of typical and atypical antipsychotic agents to 5-hydroxytryptamine-6 and 5-hydroxytryptamine-7 receptors. J Pharmacol Exp Ther 268:1403-1410

Russi G, Girotti P, Cadoni C, Di Chiara G, Consolo S (1993): Neuroleptics increase striatal acetylcholine release by a sequential D-1 and D-2 receptor mechanism. Neuroreport 4:1335-1338

Schotte A, Janssen PFM, Gommeren W, Luyten WHML, Van Gompel P, Lesage AS, De Loore K, Leysen JE (1996): Risperidone compared with new and reference antipsychotic drugs: in vitro and in vivo receptor binding. Psychopharmacology 124:57-73

Stillman MJ, Shukitt-Hale B, Galli RL, Levy A, Lieberman HR (1996): Effects of M2 antagonists on in vivo hippocampal acetylcholine levels. Brain Res Bull 41:221-226

Suzuki T, Hirooka K, Kanda K, Uesaka H, Hirooka H, Furusawa K (1998): Characterization of the neurochemical effects of N-[2-(1-azabicyclo[3,3,0]octan-5-yl)ethyl]2nitroaniline fumarate (SK-946) as a cognition activator. Biol Pharm Bull 21:704-709

Tellez S, Colpaert F, Marien M (1997): Acetylcholine release in the rat prefrontal cortex in vivo: modulation by alpha 2 -adrenoceptor agonists and antagonists. J Neurochem 68:778-785

Ueda H, Sato K, Okumura F, Misu Y (1995): L-DOPA inhibits spontaneous acetylcholine release from the striatum of experimental Parkinson's model rats. Brain Res 698:213-216

Wilkinson LO, Middlemiss DN, Hutson PH (1994): 5-HT1A receptor activation increases hippocampal acetylcholine efflux and motor activity in the guinea pig: agonist efficacy influences functional activity in vivo. J Pharmacol Exp Ther 270:656-664

Zhang W, Bymaster FP (1999): The in vivo effects of olanzapine and other antipsychotic agents on receptor occupancy and antagonism of dopamine D1,D2,D3,5HT2A and muscarinic receptors. Psychopharmacology 141: 267-278

Zhelyazkova-Savova M, Giovannini MG, Pepeu G (1999): Systemic chlorophenylpiperazine increases acetylcholine release from rat hippocampus-implication of 5-HT2C receptors. Pharmacol Res 40:165-170 